\title{
Characterization of 23S rRNA domain V mutations in gastric biopsy patients from the eastern Amazon
}

\author{
Katarine Antonia dos Santos Barile ${ }^{1 /{ }^{+}}$, Artur Luiz da Costa da Silva ${ }^{1}$, José Nazareno Xavier², \\ Mônica Baraúna Assumpção ${ }^{3}$, Tereza Cristina de Oliveira Corvelo
}

${ }^{1}$ Instituto de Ciências Biológicas ${ }^{3}$ Setor de Endoscopia, Hospital Universitário João de Barros Barreto, Universidade Federal do Pará, Rua Augusto Côrrea 1, 66075-110 Belém, PA, Brasil ²Setor de Endoscopia, Hospital Ofir Loyola, Belém, PA, Brasil

Resistance of Helicobacter pylori to clarithromycin is characterised by simple point mutations in the 23S ribosomal RNA (rRNA) gene and is responsible for the majority of cases of failure to eradicate this bacterium. In this paper, we characterised the variability of the 23S rRNA gene in biopsies of patients with gastric pathologies in the eastern Amazon (Northern Region of Brazil) using PCR and sequencing. A total of 49 sequences of $\mathrm{H}$. pylori strains were analysed and of those, $75.6 \%$ presented nucleotide substitutions: A2142G (3.3\%), T2182C (12.9\%), G2224A (6.45\%), T2215C (61.3\%), A2192G (3.3\%), G2204C (6.4\%) and T2221C (6.4\%). Of the mutations identified, four are known mutations related to cases of resistance and $16.1 \%$ are not yet described, revealing a high prevalence of mutations in the H. pylori $23 \mathrm{~S} r R N A$ gene among the strains circulating in the in the eastern Amazon. The high prevalence in individuals with gastric pathologies in the Northern Region of Brazil demonstrates the need for characterising the profile of these strains to provide correct therapy for patients, considering that mutations in this gene are normally associated with resistance to the primary medication used in controlling $\mathrm{H}$. pylori infection.

Key words: Helicobacter pylori - 23S rRNA gene - clarithromycin - resistance - mutation

Helicobacter pylori is a microorganism associated with gastric pathologies, such as peptic ulcers, chronic gastritis and stomach cancer (Dunn et al. 1997). Treatment consists of a triple therapy that combines a protein inhibitor with antibiotics, with clarithromycin being the first choice (Asaka et al. 2001, Ribeiro et al. 2003) because it is acid-stable and easily absorbed in the gastric mucosa and, therefore, effective against H. pylori (Megraud 2004, Yilmaz \& Demiray 2007). Thus, resistance by this bacterium to the antibiotic is considered to be one of the major reasons for treatment failure (Ylmaz \& Demiray 2007.).

Clarithromycin is a macrolide that has the ability to inhibit protein synthesis in $H$. pylori because of its interaction with ribosomal subunit $50 \mathrm{~S}$ in the microorganism (Versalovic et al. 1996, Garrido \& Toledo 2007). The mechanism of action for clarithromycin is to bind to the peptidyltransferase loop in domain $\mathrm{V}$ of the $23 \mathrm{~S}$ ribosomal RNA (rRNA) gene, which interferes with protein elongation, efficiently blocking bacterial protein synthesis (Yilmaz \& Demiray 2007).

It is believed that resistance to clarithromycin is a result of structural changes in the $23 \mathrm{~S}$ rRNA molecule that develop when a nucleotide substitution occurs near this ribosome binding site, impeding the drug from binding and reducing its efficacy (Graham \& Qureshi

Financial support: Capes, UFPA

+ Correspondig author: katarinebarile@gmail.com

Received 5 October 2009

Accepted 5 March 2010
2000). Mutations in domain V of the 23S rRNA gene have been associated with an important role in resistance to clarithromycin (Versalovic et al. 1996, 1997, Umegaki et al. 2000, Rimbara et al. 2007). These substitutions result in reduced ribosomal affinity for various macrolides, leading to resistance (Umegaki et al. 2000, Rimbara et al. 2007). Thus, there is a failure in eradicating the bacteria from the gastrointestinal tract, which complicates treatment of gastroduodenal diseases with which the infection is associated (Rimbara et al. 2007).

The most prevalent and well-documented mutations in the 23S rRNA gene occur in two adjacent nucleotide positions, 2142 and 2143, and include an adenine-guanine transition at position 2142 (A2142G) or 2143 (A2143G) and an adenine-cytosine transversion at position 2142 (A2142C) (Versalovic et al. 1996, 1997, Occhinalli et al. 1997). Other mutations that are associated with resistance have occasionally been observed in region $\mathrm{V}$ of the 23S rRNA gene, including G1939A, A2115G, G2141A, A2144G, C2147G, T2182C, G2224A and T2215C (Stone at al. 1996, Taylor et al. 1997, Song et al. 2000, Kim et al. 2002, Hao et al. 2004, Garrido \& Toledo 2007). The number of mutations in this region indicates that any alteration in this domain of the gene may be related to bacterial resistance to clarithromycin.

The state of Pará (PA), in the Brazilian Amazon, has a high prevalence of $H$. pylori infection in patients with gastric pathologies (Aguiar et al. 2002, Martins et al. 2005, Melo-Barbosa et al. 2009). Because of a recent increase in failure of the treatment scheme for the bacteria due to clarithromycin resistance (Magalhães et al. 2002, Hao et al. 2004, Kim et al. 2008), the objective of this paper was to demonstrate the modifications in the H. pylori $23 S$ rRNA gene isolated from eastern Amazon patients using a metagenomic approach. 


\section{PATIENTS, MATERIALS AND METHODS}

Patients - In 2007 and 2008, gastric biopsy samples were collected from patients receiving upper digestive endoscopy at the João de Barros Barreto and Ophir Loyola in the city of Belém, PA, in the Northern Region of Brazil. All patients were informed of the objective of the research and their participation was requested through a free and informed consent agreement authorising collection of samples for the study. This study was approved by the Tropical Medicine Ethical Committee at Universidade Federal do Pará. The patients submitted to the study have been diagnosed with gastritis, peptic ulcer or gastric cancer. No patient had been treated for $H$. pylori infection.

DNA isolation and PCR amplification - DNA from the samples was extracted using the phenol-chloroform method (Sambrook et al. 1989). A sample pool was created composed of the DNA from individuals known to be infected by the bacteria $(n=250)$. Amplification of DNA from patient samples and the sample pool was performed using primers 5'-CCACAGCGATGTGGTCTCAG-3' (position 1820-1839) and 5'-CTCCATAAGAGCCTGACT-3' (position 2244-2225), which amplified a 425bp fragment from region $\mathrm{V}$ of the H. pylori 23S rRNA gene (Occhinali et al. 1997). The $50 \mu \mathrm{L}$ reaction contained $75 \mathrm{mM}$ Tris- $\mathrm{HCl}, 20 \mathrm{mM} \mathrm{KCl} \mathrm{pH} \mathrm{8.4,} 1.5 \mathrm{mM}$ $\mathrm{MgCl}_{2}, 0.2 \mathrm{mM}$ deoxynucleotides, $1 \mu \mathrm{M}$ each primer, 2 U Platinum Taq DNA polymerase (Invitrogen, Life Technologies) and $100 \mathrm{ng}$ genomic DNA. The cycling program corresponded to 1 cycle at $95^{\circ} \mathrm{C}$ for $5 \mathrm{~min}, 35$ cycles at $95^{\circ} \mathrm{C}$ for $30 \mathrm{sec}, 58^{\circ} \mathrm{C}$ for $30 \mathrm{sec}$ and $72^{\circ} \mathrm{C}$ for 30 $\mathrm{sec}$ and a final extension cycle at $72^{\circ} \mathrm{C}$ for $10 \mathrm{~min}$. The amplicon of $425 \mathrm{bp}$ was visualised on a $2 \%$ agarose gel.

Genomic sequencing - After amplification, the fragment was excised from the agarose gel, purified with the GE GFX kit, inserted into a pGEM ${ }^{\circledR}$-T Easy Vector System (Promega Corp, USA) following the manufacturer's instructions and then transformed by electroporation into TOP 10 Escherichia coli. The transformed bacteria were grown on plates using $2 \mathrm{XYT}$ culture media containing ampicilin (EMS, Brazil) and X-gal (GE Health Care, USA). The recombinant clones were selected and grown in deep well plates with TARTOFF broth containing ampicilin. Recombinant clones were isolated using a miniprep and then sequenced in a MegaBACE1000 automatic isolator (GE).

Sequence analysis - The resulting sequences were aligned and manually edited with the ClustalW application using the Bioedit sequence alignment editor 7.0.0 - BioEdit software (Hall 1999), with GenBank accession sequence $\mathrm{U} 27270$ as the reference.

\section{RESULTS}

Sequencing of the domain $\mathrm{V}$ fragment of the $23 \mathrm{~S}$ rRNA gene of $H$. pylori resulted in 49 reads, which were aligned and edited using the Bioedit application. Chimeric sequences were detectedand eliminated from the database and the remaining 41 sequences were analysed for diversity.
The domain $\mathrm{V}$ mutations of the 23S rRNA gene were determined by comparison with the reference strain (UA802) and we verified that $75.6 \%$ (31/41) of the obtained reads presented some type of nucleotide substitution in the sequence.

Among the observed substitutions, we found seven different types of mutations in different reads (Table), including four that have been described in the literature as being associated with resistance to clarithromycin (A2143G, T2182C, T2215C and G2224). Additionally, we found three novel substitutions not characterised in any previously described population: G2204C, A2192G and T2221C. None of the sequences had more than one nucleotide change.

The substitutions encountered in the sequencing reads occurred with the following prevalence: A2143G (3.3\%), T2182C (12.9\%), G2224A (6.45\%), T2215C (61.3\%), A2192G (3.3\%), G2204C (6.4\%) and T2221C (6.4\%).

The seven sequences found in this study were submitted to GenBank, generating accession GQ395614, GQ395615, GQ395616, GQ395617, GQ395618, GQ395619 and GQ395620 (Table).

\section{DISCUSSION}

The prevalence of mutations found in domain $\mathrm{V}$ of the 23S rRNA gene of $H$. pylori in patients from the Northern Region of Brazil was high; 76.5\% of the obtained sequences presented some type of nucleotide substitution. According to prior studies, alterations in this domain of the gene confer bacterial resistance to clarithromycin (Versalovic et al. 1996, Occhialini et al. 1997, Van Doorn et al. 2001, Posteraro et al. 2006, Kim et al. 2008).

It is believed that substitutions found in this $H$. pylori gene may be linked to the growing use of this antibiotic not only in eradicating $H$. pylori but also in treating respiratory tract infections (Megraud 1998, Ribeiro et al. 2003, Posteraro et al. 2006), which leads to antibiotic resistant strains. Furthermore, this bacterial species has extensive rearrangements within its genome (Dunn et al. 1997, Covacci et al. 1999, Velázquez \& Feirtag 1999) used for adapting to hosts (Suerbaum \& Josenhans 2008), mainly leading to development of resistance to antibiotics like clarithromycin.

Studies have demonstrated that the frequency of resistance to this antibiotic has varied around the world according to the geographic region and subgroups within populations (Graham 1998, Kim et al. 2008) and in recent years, a significant increase in the rates of $H$. pylori strains resistant to clarithromycin has been documented (Magalhães et al. 2002, Posteraro et al. 2006). In Europe, resistance rates are $2-24 \%$, while they are $13-18 \%$ in Japan and 12 $25 \%$ in North America (Nakamura et al. 2007). Kim et al. (2008) demonstrated an increase in cases of resistant strains reaching $85.1 \%$ in Korea that was correlated with the reduction in bacteria in individuals in that country.

In Southeastern Brazil, Magalhães et al. (2002) found a $9.85 \%$ prevalence of resistant strains and in the following year, Godoy et al. (2003) described an increase to $16 \%$. In this study, the Northern Region has a much higher rate than the average observed in the Southeastern Brazilian population, presenting four of the known mutations 
TABLE

Nucleotide substitutions verified in domain $\mathrm{V}$ of the $23 \mathrm{~S}$ gene of rRNA in Helicobacter pylori found in patients with gastric pathologies in the Northern Region of Brazil (2007-2008)

\begin{tabular}{lcccc}
\hline Clone name & Mutation $^{a}$ & Frequency & GenBank acess & Reference \\
\hline HPPAA09 & G2204C & 2 & GQ395614 & This study \\
HPPAA11 & A2192G & 1 & GQ395615 & This study \\
HPPAB09 & T2221C & 2 & GQ395616 & This study \\
HPPAH12 & A2143G & 1 & GQ395617 & Versalovic et al. (1996) \\
HPPAE09 & T2215C & 19 & GQ395618 & Song et al. (2000) \\
HPPAD10 & G2224A & 2 & GQ395619 & Hao et al. (2004) \\
HPPAA12 & T2182C & 4 & GQ395620 & Kim et al. (2002) \\
\hline
\end{tabular}

$a$ : the structure and definition of positions is in agreement with what was proposed by Taylor et al. (1997).

related to clarithromycin resistance, which may be related to heterogeneity in the H. pylori strains that colonise the different regions of Brazil (Kodaira et al. 2000).

Four known mutations were detected in this study, A2143G (Versalovic et al. 1996), T2182C (Kim et al. 2002), G2224A (Hao et al. 2004) and T2215C (Song et al. 2000), with the latter being quite prevalent (62.95\%). Also, three novel mutations were identified and characterised in bacteria within the gastrointestinal metabiome. Additionally, because these mutations are in the domain of the gene normally related to clarithromycin resistance (Versalovic et al. 1996, Occhialini et al. 1997, Ribeiro et al. 2003), new studies must be performed using culturedependent approaches to confirm association of bacterial antibiotic resistance with the novel nucleotide substitutions in domain $\mathrm{V}$ of the $23 \mathrm{~S}$ rRNA gene detected in this study.

\section{REFERENCES}

Aguiar DCP, Corvelo TC, Araújo M, Cruz EM, Daibes S, Assumpção MB 2002. Expressão dos antígenos ABH e Lewis na gastrite crônica e alterações pré-neoplásicas da mucosa gástrica. Arq Gastroenterol 39: 222-232.

Asaka M, Satoh K, Sugano K, Sugiyama T, Takahashi S, Fukuda Y, Ota H, Murakami K, Kimura K, Shimoyama T 2001. Guidelines in the management of Helicobacter pylori infection in Japan. Helicobacter 6: 177-186.

Covacci A, Telford LJ, Giudice DG, Parsonet J, Rappuoli R 1999. Helicobacter pylori virulence and genetic geography. Science 284: 1328-1333.

Dunn BE, Cohen H, Blaser MJ 1997. Helicobacter pylori. Clin Microbiol Rev 10: 720-741.

Garrido L, Toledo H 2007. Novel genotypes in Helicobacter pylori involving domain $\mathrm{V}$ of the 23S rRNA gene. Helicobacter 12: 505-509.

Godoy AP, Ribeiro ML, Benvengo YH, Vitiello L, Miranda MDEC, Mendonça S, Pedrazzoli-JR J 2003. Analysis of antimicrobial susceptibility and virulence factors in Helicobacter pylori clinical isolates. BMC Gastroenterol 11: 13-20.

Graham DY 1998. Antibiotic resistance in Helicobacter pylori: implications for therapy. Gastroenterology 15: 1272-1277.
Graham DY, Qureshi WA 2000. Antibiotic-resistant H.pylori infection and its treatment. Curr Pharm Des 6: 1537-1544.

Hall TA 1999. BioEdit: a user-friendly biological sequence alignment editor and analysis program for Windows 95/98/NT. Nucl Acids Symp Ser 41: 95-98.

Hao Q, Li Y, Zhang Z, Liu Y, Gao H 2004. New mutation points in 23s rRNA gene associated with Helicobacter pylori resistance to claritromycin in Northeast China. World J Gastroenterol 10: 1075-1077.

Kim KS, Kang JO, Eun CS, Han DS, Choi TY 2002. Mutations in the 23S rRNA gene of Helicobacter pylori associated with clarithromycin resistance. J Korean Med Sci 17: 599-603.

Kim JM, Kim JS, Kim N, Kim YJ, Kim IY, Chee YJ, Lee CH, Jung HCJ 2008. Gene mutations of 23S rRNA associated with clarithromycin resistance in Helicobacter pylori strains isolated from Korean patients. J Microbiol Biotechnol 18: 1584-1589.

Kodaira MS, Escobar AMU, Grisi S 2002. Aspectos epidemiológicos do Helicobacter pylori na infância e adolescência. Rev Saude Publica 36: 356-369.

Magalhães PP, Queiroz DDM, Barbosa DVC, Rocha GA, Mendes EN, Santos A, Correa PRV, Rocha AMC, Teixeira LM, Oliveira CA 2002. Helicobacter pylori primary resistance to metronidazol and claritromycin in Brazil. Antimicrob Agents Chemother 46: 2021-2023.

Martins LC, Corvelo TCO, Demachki S, Araujo MTF, Assumpção MB, Vilar SCAJ, Freitas FB, Barbosa HPM, Fecury AA, Amaral RKC, Santos SEB 2005. Clinical and pathological importance of $v a c \mathrm{~A}$ allele heterogeneity and $\operatorname{cagA}$ status in peptic ulcer disease in patients from North Brazil. Mem Inst Oswaldo Cruz 100: 875-881.

Megraud F 1998. Epidemiology and mechanism of antibiotic resistance in Helicobacter pylori. Gastroenterology 115: 1278-1282.

Megraud F 2004. Helicobacter pylori antibiotic resistance: prevalence, importance and advances in testing. Gut 53: 1374-1384.

Melo-Barbosa HP, Martins LC, Dos Santos SE, Demachki S, Assumpção MB, Aragão CD, Corvelo TC 2009. IL-1 and TNF- $\alpha$ polimorfisms and Helicobacter pylori. World J Gastroenterol 15: 1465-1471.

Nakamura A, Furuta T, Shirai N, Sugimoto M, Kajimura M, Soya Y, Hishida A 2007. Determination of mutations of the 23S rRNA gene of Helicobacter pylori by allele specific primer-polymerase chain reaction method. J Gastroenterol Hepatol 22: 1057-1063. 
Occhialini A, Urdaci M, Doucet-Populaire F, Bebear CM, Lamouliatte H, Megraud F 1997. Macrolide resistance in Helicobacter pylori: rapid detection of point mutations and assays of macrolide binding to ribosomes. Antimicrob Agents Chemother 41: 2724-2728.

Posteraro P, Branca G, Sanguinetti M, Ranno S, Cammarota G, Rahimi S, De Carlo M, Posteraro B, Fadda G 2006. Rapid detection of claritromycin resistance in Helicobacter pylori using a PCR-based denaturing HPLC assay. $J$ Antimicrob Chemother 57: 71-78.

Ribeiro ML, Vitiello L, Miranda MC, Bevengo YH, Godoy AP, Mendonça S, Pedrazzoli-Jr J 2003. Mutations in the 23S rRNA gene are associated with clarithromycin resistance in Helicobacter pylori isolates in Brazil. Ann Clin Microbiol Antimicrob 21: 11-15.

Rimbara E, Noguchi N, Kijima H, Yamaguchi T, Kawai T, Sasatsu M 2007. Mutantions in the 23S rRNA gene of claritromycin-resistent in Helicobacter pylori from Japan. Antimicrob Agents Chemother 30: 250-254.

Sambrook J, Fritsch EF, Maniatis T 1989. Analysis and cloning of eukaryitic genome DNA. In J Sambrook, EF Fritsch, T Maniatis, Molecular cloning: a laboratory manual, Cold Spring Harbor Laboratory Press, New York, p. 16-19.

Song HJ, Chung IS, Kim SW, Lee GM, Kim BW, Lee DS, Yang YS, Han SW, Park DH, Lee JH 2000. Antimicrobial resistance rates in Helicobacter pylori and detection of $23 \mathrm{~s}$ rRNA mutation associated with claritromycin resistance. Korean J Gastroenterol 36: 597-606.

Stone GG, Shortrdge D, Flamm RK, Versalovic J, Beyer J, Idler K, Zulawinski L, Tanaka K 1996. Identification of 23S rRNA gene mutation in claritromycin-resistant Helicobactr pylori. Helicobacter 1: 227-228.

Suerbaum S, Josenhans C 2007. Helicobacter pylori evolution and phenotipic diversification in a changing host. Nat Rev Microbiol 5: 441-452.
Taylor DE, Ge Z, Purych D, Lo T, Hiratsuka K 1997. Cloning and sequence analysis of two copies of $23 \mathrm{~S}$ rRNA gene from Helicobacter pylori and association of claritromycin resistance with $23 \mathrm{~S}$ rRNA mutations. Antimicrob Agents Chemother 41: 2612-2628.

Umegaki N, Shimoyama T, Nishiya D, Suto T, Fukuda S, Munakata A 2000. Clarithromycin-resistance and point mutations in the $23 \mathrm{~S}$ rRNA gene in Helicobacter pylori isolates from Japan. $J$ Gastroenterol Hepatol 15: 906-909.

Van-Doorn LJ, Glupczynski Y, Kusters JG, Megraud F, Midolo P, Maggi-Solca N, Queiroz DMM, Nouhan N, Stet E, Quint WGV 2001. Accurate prediction of macrolide resistance in Helicobacter pylori by a PCR line probe assay for detection of mutations in the 23S rRNA gene: multicenter validation study. Antimicrob Agents Chemother 45: 1500-1504.

Velazquez M, Feirtag JM 1999. Helicobacter pylori: characteristics, pathogenicity, detection methods and mode of transmission implicating foods and water. Int J Food Microbiol 53: 95-104.

Versalovic J, Osato MS, Spakovsky K, Dore MP, Redly R, Stone GG, Shorttridge D, Flamm RK, Tanaka KS, Graham DY 1997. Point mutations 23s rRNA gene of Helicobacter pylori associated with different levels os claritromycin resistance. $J$ Antimicrob Chemother 40: 283-286.

Versalovic J, Shortridge D, Kibler K, Griffy MV, Beyer J, Flamm RK, Tanaka SK, Graham DY, Go MF 1996. Mutations in 23S rRNA are associated with clarithromycin resistance in Helicobacter pylori. Antimicrob Agents Chemother 40: 477-480.

Ylmaz O, Demiray E 2007. Clinical role and importance of fluorescence in situ hybridization method in diagnosis of $H$. pylori infection and determination of claritromycin resistance in $\mathrm{H}$. pylori eradication therapy. World J Gastroenterol 13: 671-675. 